\title{
Wildfire smoke in the Siberian Arctic in summer: source characterization and plume evolution from airborne measurements
}

\author{
J.-D. Paris ${ }^{1}$, A. Stohl ${ }^{2}$, P. Nédélec ${ }^{3}$, M. Yu. Arshinov ${ }^{4}$, M. V. Panchenko ${ }^{4}$, V. P. Shmargunov ${ }^{4}$, K. S. Law ${ }^{5}$, B. D. Belan ${ }^{4}$, \\ and P. Ciais ${ }^{1}$ \\ ${ }^{1}$ Laboratoire des Sciences du Climat et de l'Environnement/IPSL, CNRS-CEA-UVSQ, Orme des Merisiers, \\ CEA Saclay, Gif sur Yvette, France \\ ${ }^{2}$ Norwegian Institute for Air Research, Kjeller, Norway \\ ${ }^{3}$ Laboratoire d'Aérologie, CNRS-UPS, Toulouse, France \\ ${ }^{4}$ Institute of Atmospheric Optics, SB-RAS, Tomsk, Russia \\ ${ }^{5}$ UPMC Univ. Paris 06, Univ. Versailles St-Quentin, CNRS/INSU, LATMOS-IPSL, Paris, France
}

Received: 27 July 2009 - Published in Atmos. Chem. Phys. Discuss.: 2 September 2009

Revised: 24 November 2009 - Accepted: 1 December 2009 - Published: 11 December 2009

\begin{abstract}
We present airborne measurements of carbon dioxide $\left(\mathrm{CO}_{2}\right)$, carbon monoxide $(\mathrm{CO})$, ozone $\left(\mathrm{O}_{3}\right)$, equivalent black carbon (EBC) and ultra fine particles over NorthEastern Siberia in July 2008 performed during the YAKAEROSIB/POLARCAT experiment. During a "golden day" (11 July 2008) a number of biomass burning plumes were encountered with $\mathrm{CO}$ mixing ratio enhancements of up to $500 \mathrm{ppb}$ relative to a background of $90 \mathrm{ppb}$. Number concentrations of aerosols in the size range $3.5-200 \mathrm{~nm}$ peaked at $4000 \mathrm{~cm}^{-3}$ and the EBC content reached $1.4 \mu \mathrm{g} \mathrm{m}^{-3}$. These high concentrations were caused by forest fires in the vicinity of the landing airport in Yakutsk where measurements in fresh smoke could be made during the descent. We estimate a combustion efficiency of $90 \pm 3 \%$ based on $\mathrm{CO}$ and $\mathrm{CO}_{2}$ measurements and a $\mathrm{CO}$ emission factor of $65.5 \pm 10.8 \mathrm{~g} \mathrm{CO}$ per kilogram of dry matter burned. This suggests a potential increase in the average northern hemispheric CO mixing ratio of 3.0-7.2 ppb per million hectares of Siberian forest burned. For BC, we estimate an emission factor of $0.52 \pm 0.07 \mathrm{~g} \mathrm{BC} \mathrm{kg}^{-1}$, comparable to values reported in the literature. The emission ratio of ultra-fine particles $(3.5-200 \mathrm{~nm})$ was $26 \mathrm{~cm}^{-3}$ (ppb CO) $)^{-1}$, consistent with other airborne studies.

The transport of identified biomass burning plumes was investigated using the FLEXPART Lagrangian model. Based on sampling of wildfire plumes from the same source but with different atmospheric ages derived from FLEXPART,
\end{abstract}

we estimate that the e-folding lifetimes of EBC and ultra fine particles (between 3.5 and $200 \mathrm{~nm}$ in size) against removal and growth processes are 5.1 and 5.5 days respectively, supporting lifetime estimates used in various modelling studies.

\section{Introduction}

Vegetation fires, either man made or natural, constitute a major source of pollutants to the atmosphere and have an impact on air quality at the hemispheric scale. In particular Siberian forest fires are known to be a major extratropical source of carbon monoxide (CO), as well as a significant source of black carbon (BC; Lavoué et al., 2000) and other climate-relevant species to the atmosphere, dominating other biomass burning sources at high latitudes. Siberian fires emitted $26 \pm 27 \mathrm{Tg}$ CO per year on average ( \pm 1 std dev) over the period $1997-2007$, i.e. $56 \%$ of the total extratropical fire $\mathrm{CO}$ emissions in the northern hemisphere $(46 \pm 32 \mathrm{Tg} \mathrm{CO}$; GFEDv2; van der Werf et al., 2006). The large interannual variability in fire occurrence over Siberia is a major driving factor for the variability of $\mathrm{CO}$ in the northern hemisphere atmosphere (Wotawa et al., 2001). Boreal forest fire plumes also degrade Arctic air quality (Wofsy et al., 1994; Stohl et al., 2006; Generoso et al., 2007; Quinn et al., 2008; Warneke et al., 2009).

\section{Correspondence to: J.-D. Paris}

(jean-daniel.paris@1sce.ipsl.fr)

Published by Copernicus Publications on behalf of the European Geosciences Union. 
$\mathrm{BC}$ is a light-absorbing fraction of the total aerosol emitted by forest fires. It represents a highly variable fraction $(8 \% \pm 6 \%)$ of the total aerosol mass (Reid et al., 2005), with the bulk (between half and two thirds) consisting of organic carbon. BC from boreal forest fires has a significant radiative impact on the Arctic atmosphere through midtroposphere warming and deposition on snow (Quinn et al., 2008; Flanner et al., 2007), especially in spring. Little is known about emission, transport and deposition of $\mathrm{BC}$ from Siberian forest fires to the Arctic. Based on transport model calculations, Stohl (2006) argued that boreal forest fires, especially Siberian fires, are the largest source of BC to the Arctic in summer, exceeding all contributions from anthropogenic sources. In a measurement-based modelling study, Generoso et al. (2007) found that the 2003 Russian fires emitted $0.5 \mathrm{TgC}$ as $\mathrm{BC}$, and contributed about $40-56 \%$ of the total $\mathrm{BC}$ mass deposited north of $75^{\circ} \mathrm{N}$. However, Koch and Hansen (2005) find this contribution generally secondary compared to South Asian anthropogenic and tropical biomass burning sources, due to efficient transport in their model.

The impact of Siberian wildfires on the atmospheric composition is very difficult to determine for a number of reasons. Characterization of fire plumes over Siberia is largely lacking (see e.g. Nédélec et al., 2005). Areas burned, biomass fraction consumed, combustion efficiency, height of plume injection into the atmosphere and emission ratios are all highly uncertain for Siberia. Ground-truth data from Siberia is largely lacking. A few prescribed fires provided insight into Siberian forest fire processes and values for emission ratio of various species (FIRESCAN Science Team, 1996; Cofer et al., 1996, 1998; McRae et al., 2006). Annual areas burned are known to have been underestimated by earlier official data (Conard et al., 2002). Van der Werf et al. (2006) used burned area information from MODIS, but (1) the resolution of MODIS is coarse for this application, and (2) validation with high resolution Landsat data show for Africa an underestimation of burned area by $40 \%$ for $60 \%$ of land cover (Lehsten et al., 2009). Further, these detections do not fully capture the spatio-temporal variability of fires because of infrequent satellite overpasses or clouds. Furthermore, chemistry-transport models are very sensitive to the injection height of fire emissions (e.g. Turquety et al., 2007), which depends both on synoptic conditions and type of fire.

Although sparse, aircraft observations can provide valuable constraints on the emission factors (e.g. Ward et al., 1991), injection heights and subsequent transport (e.g. Andreae et al., 1998). Here we investigate the outflow from major fires burning in Siberia in July 2008. Our instrumented aircraft crossed several plumes originating from the same fire region. These observations provide insight in the injection of the forest fire plume, its transport toward the Arctic, its evolution and removal processes.

\section{Methods}

\subsection{Field sampling}

YAK-AEROSIB (Airborne Extensive Regional Observations in Siberia) performs a series of airborne measurement campaigns over Siberia. Two campaigns were carried out between 7 and 29 July 2008 in a collaborative effort with the POLARCAT (Polar Study using Aircraft, Remote Sensing, Surface Measurements and Models, of Climate, Chemistry, Aerosols, and Transport) programme, following three previous campaigns in 2006 and 2007 (Paris et al., 2008, 2009b). The campaign consisted of two large loops in North and Central Siberia (Fig. 1a), intended to document the distribution of $\mathrm{CO}_{2}, \mathrm{CO}$ and $\mathrm{O}_{3}$ as well as aerosols in the Siberian troposphere. As a contribution to the POLARCAT programme, the flight route (which had to be fixed prior to the campaign) was chosen to sample as many different air masses as possible with a flight pattern consisting of frequent ascents and descents between close to the ground and $7 \mathrm{~km}$ altitude. Here we focus on data obtained during flight 17 on 11 July 2008, a south-bound leg starting from the Siberian Arctic coast. The aircraft departed from Chokurdakh $\left(70^{\circ} \mathrm{N}, 147^{\circ} \mathrm{E}\right)$ and landed in Yakutsk $\left(62^{\circ} \mathrm{N}, 130^{\circ} \mathrm{E}\right)$ (Fig. 1b). Fires were burning near Yakutsk (Fig. 1b), and several plumes from these fires were encountered during the flight.

\subsection{Instruments}

The airborne instruments are documented elsewhere (Paris et al., 2008, 2009a) and, thus, only short descriptions are provided here, except for the aethalometer measuring equivalent $\mathrm{BC}$, which has not been described previously. Concentrations of ultra-fine and fine particles in three size ranges $(3-5.5,5.5-20.5,20.5-200 \mathrm{~nm})$ were measured with an automated diffusion battery (ADB; see Arshinov et al., 2007; Paris et al., 2009a, and references therein). The ADB coupled with a condensation particle counter (CPC) has an additional aspiration unit to compensate changing ambient pressure and changing flow rate. All particle concentrations are reported at standard pressure and temperature (STP) conditions. Particle concentrations in 15 size bins in the range 0.3-20 $\mu \mathrm{m}$ were measured using a GRIMM 1.108 instrument (GRIMM Aerosol Technik GmbH \& Co. KG, Germany). Equivalent black carbon (EBC) mass concentration was measured using an aethalometer based on diffuse attenuation of light by particles after collection on a filter (Panchenko et al., 2000). The wavelength ranges between 0.4 and $1.1 \mu \mathrm{m}$ with maximum near $0.9 \mu \mathrm{m}$. This instrument is sensitive to submicron particles. The measured light absorption can be converted into EBC mass concentration $M_{\mathrm{BC}}$ using Eq. (1): 


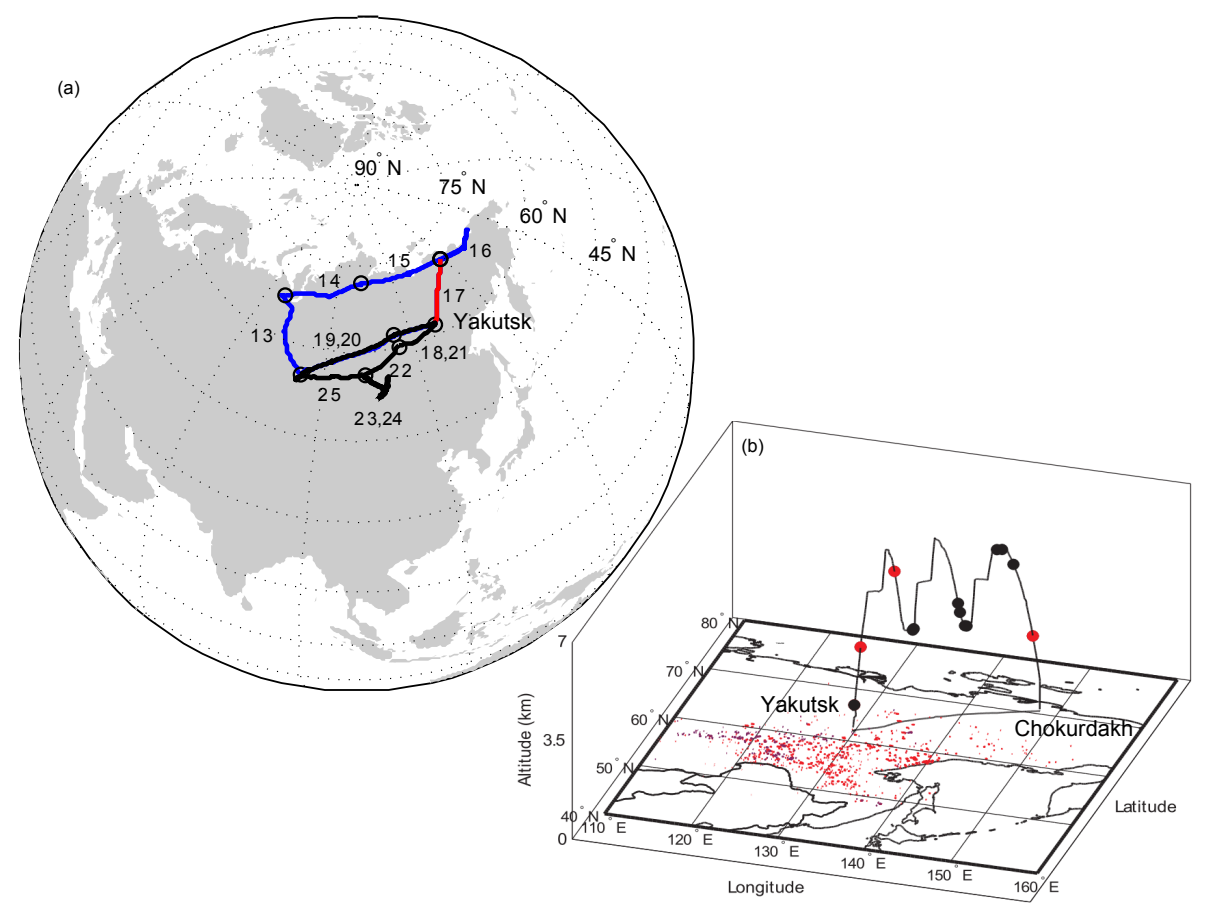

Fig. 1. (a) Flight route for the July 2008 campaigns. In blue: northern Siberia loop; in black: central Siberia loop. Flight 17 on 11 July is highlighted in red. (b) Itinerary of flight 17 from Chokurdakh (North) to Yakutsk. Area burnt by forest fires (Sukhinin et al., 2004) during the period 1-7 July is indicated in red, between 7-14 July in blue. Along the aircraft trajectory, individual plumes with $\mathrm{CO}>120 \mathrm{ppb}$ are marked by black dots, and $\mathrm{CO}>150 \mathrm{ppb}$ by red dots.

$M_{\mathrm{BC}}=\frac{S_{\mathrm{f}} \cdot \ln \left(I_{1} / I_{2}\right)}{k \cdot V \cdot t} \cdot 10^{5}$

where $S_{\mathrm{f}}$ is the filter area $\left(\mathrm{cm}^{2}\right), I_{1}$ and $I_{2}$ the signal before and after pumping, $k$ the mass coefficient $\left(28 \mathrm{~cm}^{2} \mu \mathrm{g}^{-1}\right) \mathrm{ob}-$ tained during calibration, $V$ the flow rate $(1 / \mathrm{min})$, and $t$ the time of pumping ( $\mathrm{min})$. The sensitivity of the aethalometer is $\sim 0.01 \mu \mathrm{g} \mathrm{m}^{-3} \mathrm{EBC}$.

$\mathrm{CO}$ and $\mathrm{O}_{3}$ mixing ratios were measured by modified commercial gas analysers Thermo 48C and Thermo 49 (Thermo Environmental Instruments, USA; see Nédélec et al., 2003; Paris et al., 2008). $\mathrm{CO}_{2}$ was measured using a modified LiCor 6262 improved with pressure and flow rate control and temperature stability, as well as three calibration gases with mixing ratios bracketing ambient ones (Paris et al., 2008). The instrument precision is $\sim 0.15 \mathrm{ppm}$.

\subsection{Modelling of air mass transport}

The origin of air masses and the contribution of biomass burning to $\mathrm{CO}$ enhancements was investigated using the FLEXPART Lagrangian model (Stohl et al., 2005; Seibert and Frank, 2004). FLEXPART calculates the trajectories of tracer particles using the mean winds interpolated from meteorological analysis fields plus random motions representing turbulence and convection. Results presented here use ECMWF (European Centre for Medium-Range Weather Forecasts) analysis fields, although GFS (Global Forecast
System of NOAA/NCEP) fields were used, too, as differences between the two simulations allow estimating the transport error. Both data sets were used at $0.5^{\circ} \times 0.5^{\circ}$ resolution and 3-h time resolution. The ECMWF data used has 91 vertical levels, whereas for the GFS data only 26 pressure levels were available. Both backward and forward simulations were performed. While the forward simulations served to investigate the extension of fire plumes, the backward simulations were used to analyse transport pathways from potential source regions to the aircraft position. Each backward simulation consists of 40000 particles released whenever the aircraft has moved $0.15^{\circ}$ in latitude or longitude, or $10 \mathrm{hPa}$ in altitude. Released particles were followed 20 days backward in time and an emission sensitivity (ES) was calculated at a resolution of $0.5^{\circ}$, which can be folded with available emission fluxes to calculate source contributions (e.g., Stohl et al., 2007). Results are available at http://zardoz.nilu.no/ andreas/YAK/.

Biomass burning (BB) emission estimates for $\mathrm{CO}$ are based on active fire detections by the MODIS instruments onboard the Aqua and Terra satellites (Giglio et al., 2003) (see http://maps.geog.umd.edu/products/MODIS_ Fire_Users_Guide_2.2.pdf) and using the algorithm described by Stohl et al. (2007). The impact of cloud cover on MODIS fires detection is reduced by assuming that fires are burning for $48 \mathrm{~h}$, a possibly longer time than the cloud cover 

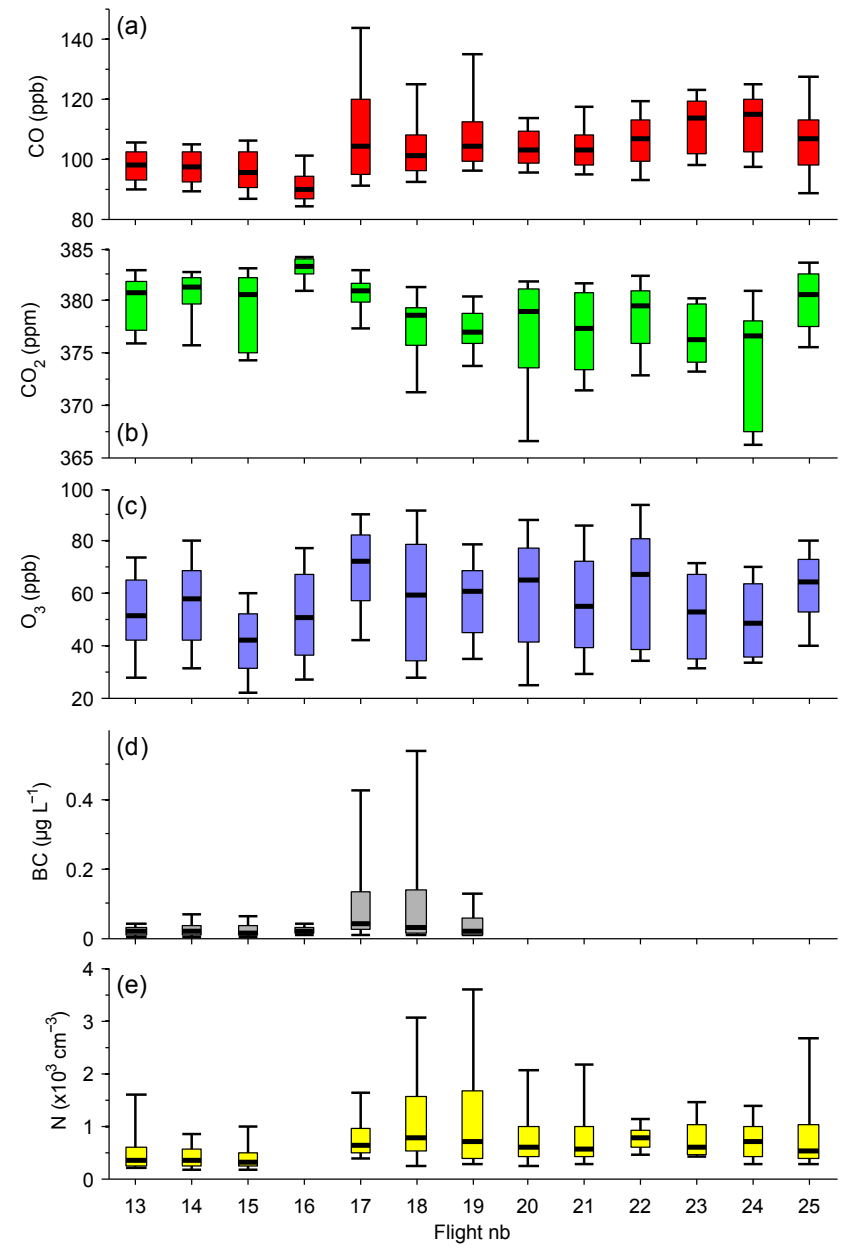

Fig. 2. Statistical summary of all observations for each flight in July 2008. The central bar indicates the median, the box indicates the inter-quartile range, and the error bars extend from the 10th to the 90th percentiles. (a) $\mathrm{CO}$, (b) $\mathrm{CO}_{2}$, (c) $\mathrm{O}_{3}$, (d) $\mathrm{EBC}$, (e) ultrafine (between 3 and $200 \mathrm{~nm}$ ) particle total number concentrations. $\mathrm{BC}$ data are not available for flights $20-25$, and particle number concentrations are not available for flight 16.

persistence over the fire locations. Unfortunately, this also smoothes the source strength over both days and leads to somewhat less episodic behaviour than in reality. Forest fire emissions are injected homogeneously between the ground and $3 \mathrm{~km}$ altitude, as we found that it provided a significant improvement over simple ground-level injection in the simulation of the smoke plumes. Anthropogenic emissions were taken from the EDGAR 3.2 Fast Track 2000 dataset (Olivier et al., 2001). The "age" of each fire plume identified in this study was calculated by taking the average age of the FLEXPART fire $\mathrm{CO}$ tracer at the time of the maximum observed CO.

For the forward simulations, a $\mathrm{CO}$ and a $\mathrm{BC}$ tracer were initialized at the exact location of every fire detected in the northern hemisphere, with emissions estimated as described

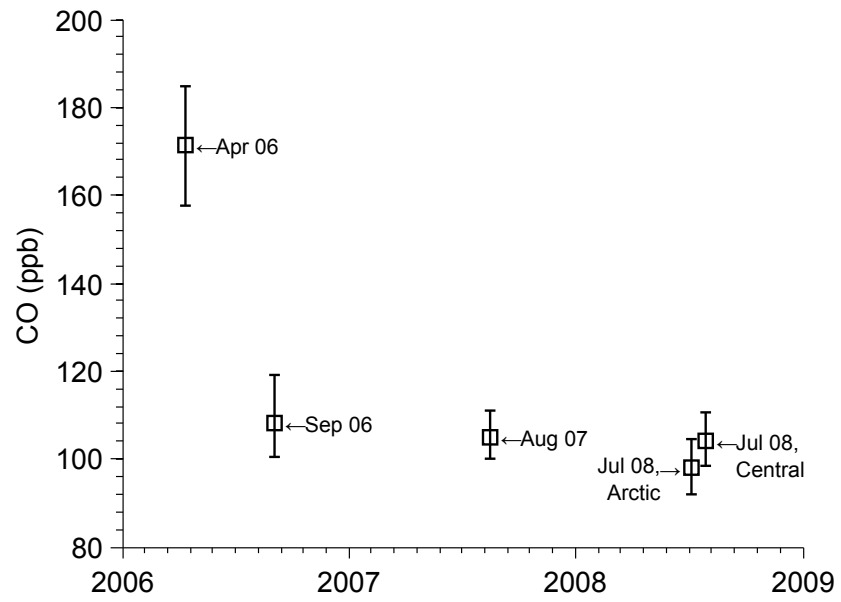

Fig. 3. Comparison of $\mathrm{CO}$ median mixing ratios and interquartile range (error bars) for July 2008 and previous YAK-AEROSIB campaigns.

above. The simulation covered the period March-July 2008 and particles in this simulation were dropped from the simulation after 20 days. A maximum of 18 million particles were simultaneously present in the simulation. The $\mathrm{BC}$ tracer was subject to wet and dry deposition parameterizations in FLEXPART, while the CO tracer was only removed when particles were dropped after 20 days.

\section{Results and discussion}

Figure 2 shows the frequency distributions of aerosols and trace gases in Siberia during the 2008 campaign flights. A $\mathrm{CO}$ background emerges from this distribution, with median mixing ratios generally between 90 and $100 \mathrm{ppb}$. Comparing the $\mathrm{CO}$ distribution with that of the three previous measurement campaigns (Paris et al., 2008, 2009b), irrespective of altitude, suggests that overall $\mathrm{CO}$ mixing ratios observed during this campaign were within the range observed during previous summer campaigns (Fig. 3). Higher $\mathrm{CO}$ mixing ratios ( $160-180 \mathrm{ppb})$ were only observed in April 2006, a consequence of the seasonal cycle of $\mathrm{CO}$. The measurements are not biased by sampling strategy because the campaign itinerary needs to be announced to Russian authorities a long time in advance and therefore targeting of particular plumes is impossible. Figure 3 also reveals that northern Siberia CO mixing ratios are consistently lower than those sampled in central Siberia, probably due to the sampling of a different air mass within the polar dome at the northern leg of the flight track.

Analysing the trace gas and aerosol distribution during the 2008 campaigns on a flight by flight basis, more elevated $\mathrm{CO}$ mixing ratios are found in eastern-central Siberia (Fig. 2a, flights 17-19) and at low levels over Lake Baikal (flights 23-24) than in other regions. $\mathrm{CO}_{2}$ and $\mathrm{O}_{3}$ mixing 


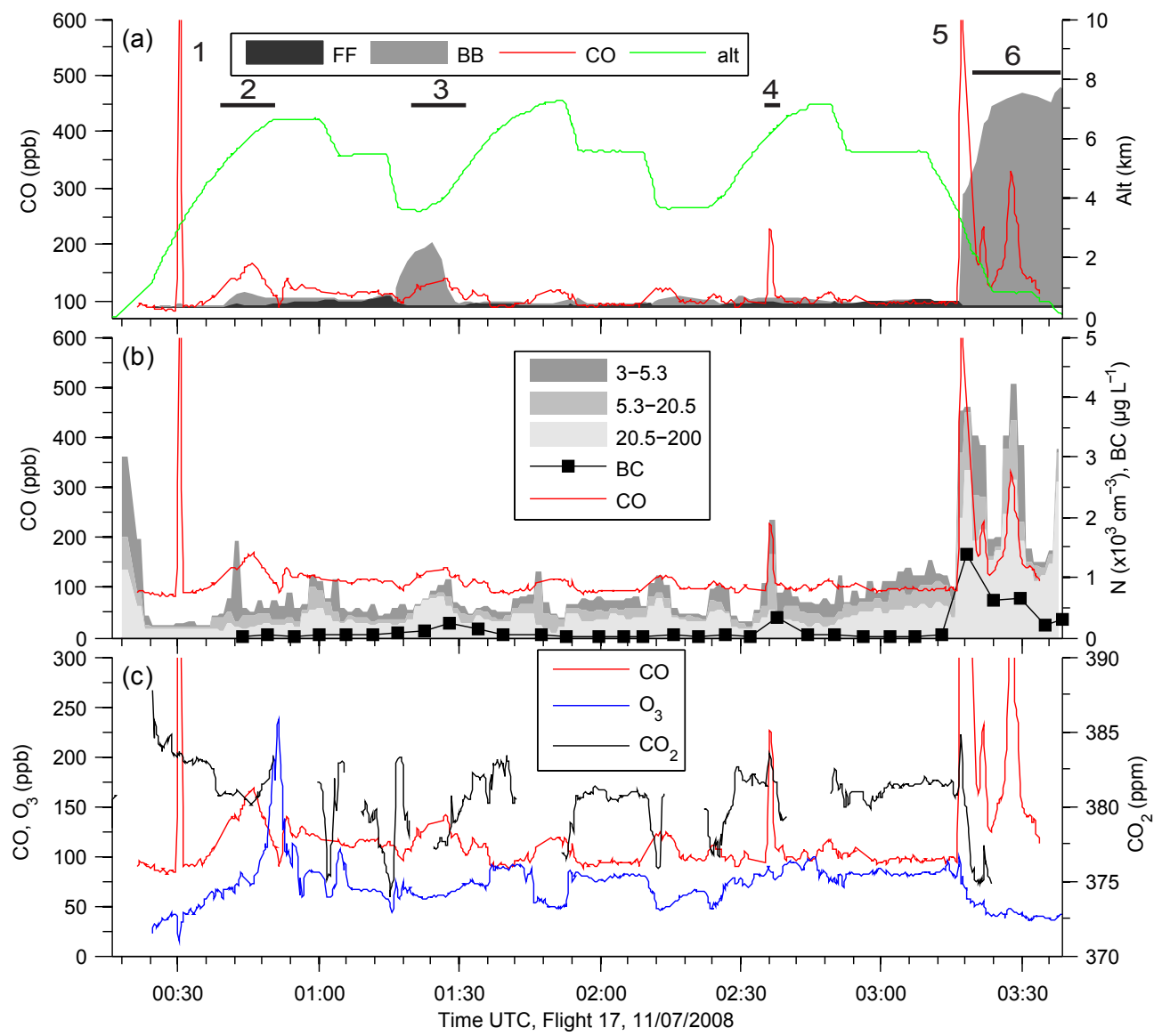

Fig. 4. Tracer time series during flight 17 on 11 July 2008. (a) observed CO (red line) and CO mixing ratios simulated with FLEXPART (shaded area). Simulated CO mixing ratios from biomass burning (BB, light grey) and fossil fuel burning (FF, dark grey) were accounted for during the last 20 days before the flight and an arbitrary background of $90 \mathrm{ppb}$ was added. Aircraft altitude is shown in green. Six events correspond to high CO plume encounters. Events 2, 3, 4 and 6 are highlighted (thick bars) where FLEXPART identifies a dominant BB contribution. (b) Observed ultra-fine particles number concentration (shaded area) and black carbon. CO is plotted again in red. The particles are divided in three size bins: 3-5.3 nm (dark grey), 5.3-20.5 nm (medium grey) and 20.5-200 nm (light grey). (c) Observed mixing ratios of $\mathrm{CO}_{2}, \mathrm{O}_{3}$ and $\mathrm{CO}$.

ratios vary considerably and are not well correlated with $\mathrm{CO}$. They are suggested to be determined largely by the variability in exchange processes at the surface. For instance, flights over Northern Siberia and tundra typically revealed vertical profiles with weak or absent $\mathrm{CO}_{2}$ gradient toward the ground, whereas at lower latitudes $\mathrm{CO}_{2}$ decreases strongly towards the ground (not shown) because of efficient $\mathrm{CO}_{2}$ uptake by trees for photosynthesis (Nakazawa et al., 1997; Paris et al., 2009b). Similarly, $\mathrm{O}_{3}$ spatial variability in the lower troposphere could be largely driven by deposition processes, with a possible contribution to variability from the import of stratospheric $\mathrm{O}_{3}$. Paris et al. (2009b) found that in spring, tropospheric $\mathrm{O}_{3}$ over Siberia was negatively correlated $(R=-0.53)$ to the residence time of the air mass close to the ground $(<300 \mathrm{~m})$ over the region and positively correlated to the model stratospheric tracer $(R=0.43)$. In summer, the negative correlation with local residence time is enhanced (up to $R=-0.76$ ) but the clear correlation with stratospheric contribution is lost.

The more elevated CO levels during flights 17-19 are associated with strongly enhanced EBC and ultrafine particle concentrations, which can be attributed to influence from biomass burning. Of the three flights, flight 17 is clearly the one with the strongest $\mathrm{CO}$ and EBC enhancements and, thus, the remainder of this paper analyzes the data obtained during this flight in detail.

\subsection{Identification of biomass burning influence}

Figure 4 shows the $\mathrm{CO}, \mathrm{O}_{3}$ and aerosol concentrations measured along flight 17 . Large $\mathrm{CO}$ enhancements were encountered during this flight, with maximum $\mathrm{CO}$ mixing ratios of about $600 \mathrm{ppb}$, an enhancement of almost $500 \mathrm{ppb}$ over a background of $90 \mathrm{ppb}$. Over Siberia, remote from anthropogenic emission sources, elevated $\mathrm{CO}$ likely originates 

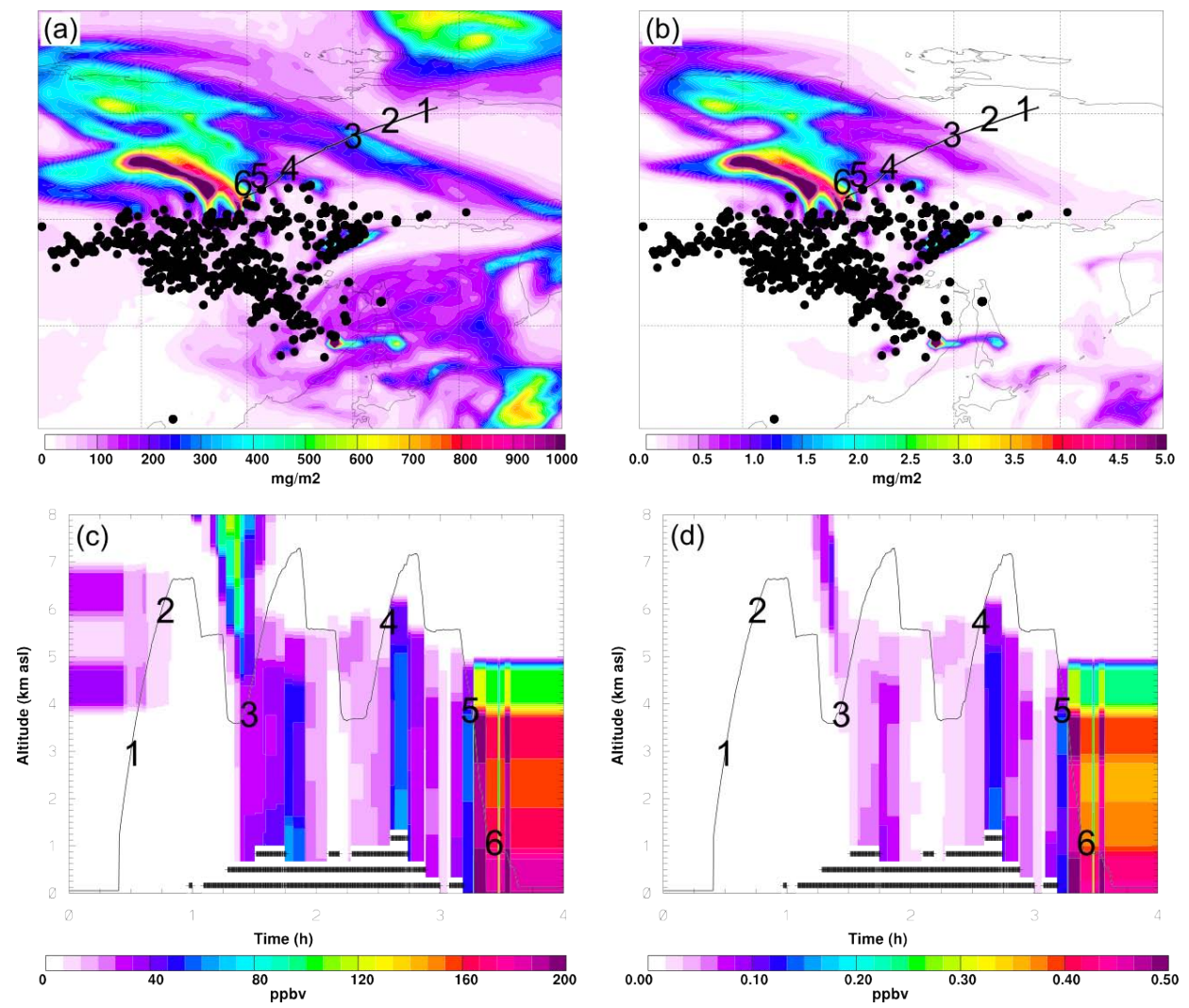

Fig. 5. Results from the FLEXPART forward simulation of biomass burning CO (left) and BC (right) tracers over Northern Siberia on 11 July 2008. Upper panels show total atmospheric columns, lower panel are curtains through the model output along the flight track. The flight track is shown as a black line in all panels; striped areas in the lower panels indicate model topography. Note that while the FLEXPART output is gridded at $1 \mathrm{~km}$ vertical resolution (apparent "steps" in lower panels), smaller-scale processes are taken into account in the simulation and are reflected in the model output. Black dots represent active fires detected by MODIS. Approximate position and number of plumes is given in each panel.

from wildfires. The origin of these elevated $\mathrm{CO}$ plumes was tested with the FLEXPART Lagrangian model (Fig. 4a). According to the model anthropogenic emissions had a negligible influence during the entire flight in this remote region, with a predicted median anthropogenic $\mathrm{CO}$ contribution (integrated over the last 20 days before the flight) of $0.6 \mathrm{ppb}$ (interquartile range 0.5-2.4 ppb; black shading in Fig. 4a). On the contrary, FLEXPART suggests substantial influence from biomass burning (median $2.4 \mathrm{ppb}$, interquartile range 0.4-9.5 ppb; grey shading in Fig. 4a). The simulated high $\mathrm{CO}$ mixing ratios due to the influence of biomass burning (BB) plumes correctly match some of the observed CO enhancements (Fig. 4a). The modelled amplitude of CO mixing ratios, however, appears to be often over- or underestimated and a thin smoke layer shortly after take-off in Chokurdakh is missed altogether by the model. Reasons for the model shortcomings in addition to potential transport errors (e.g. not fully resolving the boundary layer height diurnal cycle due to the 3-hourly temporal resolution of the meteorological input data) are (1) the high uncertainty of the emissions associated with each individual fire detection from satellite, (2) the poor temporal resolution of the MODIS fire detections and missing detections in the presence of clouds, and (3) uncertain injection heights into the atmosphere of the biomass burning emissions.

Using the algorithm used by FLEXPART, we estimate that a total of $27 \mathrm{MtCO}$ were emitted for fire detections over forested areas in Siberia (defined roughly as the region between $30-180^{\circ} \mathrm{E}$ and $40-80^{\circ} \mathrm{N}$ ), and another $30 \mathrm{Mt} \mathrm{CO}$ were emitted by fires detected over other land use types, between March and October 2008.

The results of a FLEXPART forward run are broadly consistent with our observations (Fig. 5). For instance, the thin smoke layer labelled plume 1 is found near the edge of an aged and re-circulated biomass burning plume advected from the north. Ageing of the fire plume is denoted by the decrease in $\mathrm{BC}$ relative to $\mathrm{CO}$ in older plumes, in agreement with the measurements (early in the flight, after take-off in the north). The FLEXPART forward simulation is also in agreement with the smoke patterns seen in a MODIS image (Fig. 6) and with spaceborne $\mathrm{CO}$ measurements taken on the same day by the IASI (Infrared Atmospheric Sounding Interferometer) 


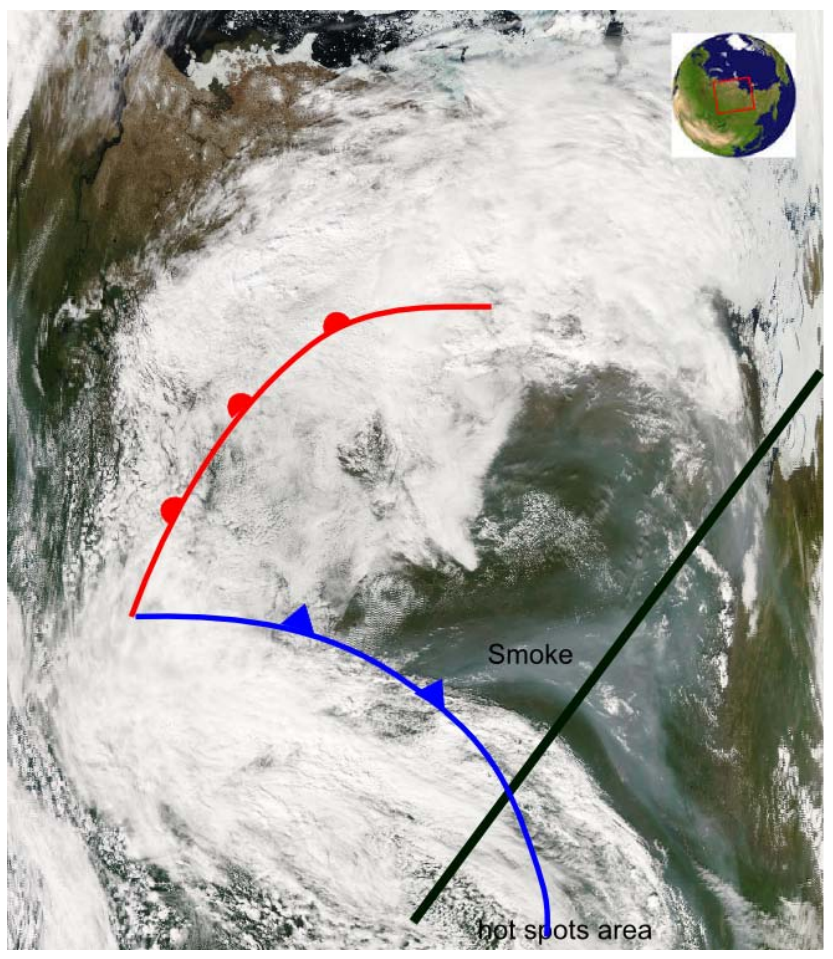

Fig. 6. Aqua/MODIS image over Siberia at 2008/193 (11/07/08) at 04:45 UTC, showing an area coincident with flight 17 (approximate flight track is shown in black). Approximative delineation of the fronts present at 12:00 UTC is shown in blue and red. A higher resolution version with hot spots indicated is available at http://rapidfire.sci.gsfc.nasa.gov/realtime/2008193/.

instrument (Pommier et al. 2009), illustrating the dominant fire origin of the $\mathrm{CO}$ enhancements. Emissions from fires located near Yakutsk at the time of the campaign were transported to the north on average but significant frontal activity sheared and isolated the BB emissions in several separate plumes. According to the Russian Hydrometcenter weather chart, a strong low at $110^{\circ} \mathrm{E}, 67^{\circ} \mathrm{N}$ was centered to the west of the flight, provoking vigorous frontal activity and attracting the fire plumes close to the source. A cold front was located in the middle of the flight track, which marks correspondingly the steep gradient between smoke and clean air in the cold air mass, and an occluded front was located near Yakutsk, where the highest $\mathrm{CO}$ and $\mathrm{BC}$ concentrations are found (Fig. 5). Consequently, a thick cloud deck was present over large parts of the flight (Fig. 6).

\subsection{Characterization of background air composition}

Mixing ratios in plumes are mostly reported as excess above background. The $\mathrm{CO}$ background was determined to be $90 \pm 10 \mathrm{ppb}$ (when excluding CO plumes; Paris et al., 2008). The ultra fine (3-200 nm) particles' background concentration was taken at $400 \mathrm{~cm}^{-3}$, which is approximately the 20th percentile of the distributions, and reflects typical concentra-

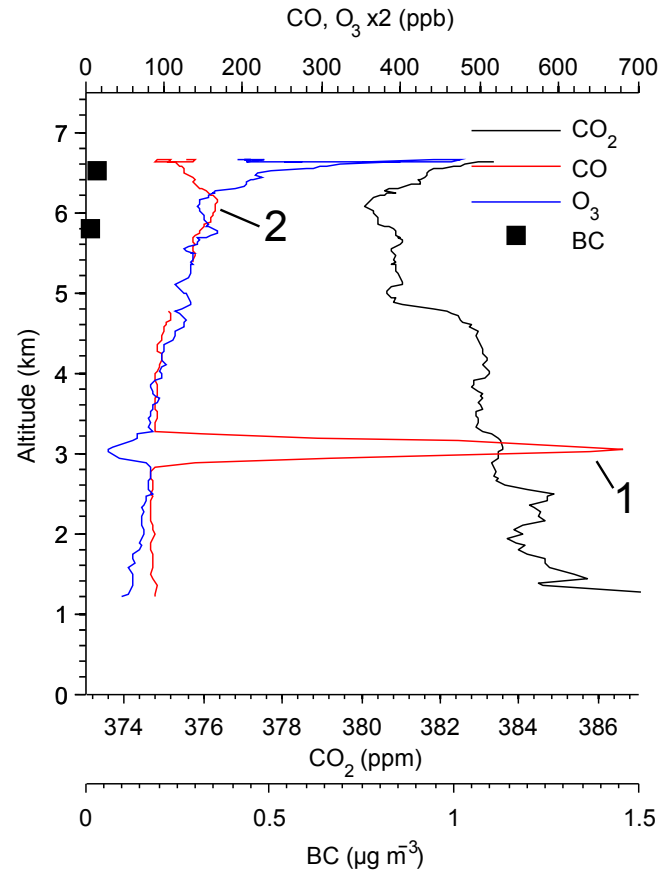

Fig. 7. Vertical profiles of $\mathrm{CO}$ (red line), $\mathrm{CO}_{2}$ (black line), $\mathrm{O}_{3}$ (blue line) and EBC (black squares) shortly after take off from Chokurdakh. Position of plumes 1 and 2 is indicated.

tions in CO-poor regions (Fig. 4b). Similarly, the observed EBC background is estimated to be $\sim 210^{-2} \mu \mathrm{g} \mathrm{m}^{-3}$, near detection limit.

Due to its high temporal (depending on recent ecosystem net primary production) and spatial variability (due to the gradient across the $\mathrm{BL}$ entrainment zone), the $\mathrm{CO}_{2}$ background cannot be readily estimated from measurements in surrounding air masses. We interpolated a relevant background value from measurements in clean air $(\mathrm{CO}<110 \mathrm{ppb})$ within the boundary layer elsewhere during the campaign, at similar local time and latitude. The resulting $\mathrm{CO}_{2}$ background valid for recent smoke observed at low levels during the flight on 11 July (plumes 5 and 6 ) is $372.3 \pm 2.5 \mathrm{ppm}$ (median \pm std dev). This value is used for background mixing ratio of $\mathrm{CO}_{2}$ measured far from the boundary layer in Table 1. We observe from the last profile an apparent background of $\sim 374 \pm 1 \mathrm{ppm}$ (Fig. 8). Since this value has less uncertainty associated with it, it is used for measurements obtained in the boundary layer during the descent near Yakutsk.

\subsection{Characterization of individual plumes}

We identified six distinct (from the aircraft sampling perspective) BB plumes for further analysis (labelled in Fig. 4a). Plume 1 has a very high $\mathrm{CO}$ enhancement above background (up to $\Delta \mathrm{CO}=500 \mathrm{ppb}$, average $362 \mathrm{ppb}$; see Table 1). This plume has a thickness of $\sim 500 \mathrm{~m}$, and was encountered at 
Table 1. Species mixing ratio and enhancements above background, ratio to reference species $\mathrm{CO}$ and $\mathrm{CO}_{2}$ and FLEXPART age of plumes. $1-\sigma$ mixing ratios uncertainties due to background estimation are reported.

\begin{tabular}{lcccccc}
\hline Plumes & 1 & 2 & 3 & 4 & 5 & 6 \\
\hline $\mathrm{CO}_{2}(\mathrm{ppm})$ & 383.5 & 380.8 & 377.6 & 382.5 & 379.7 & 375.4 \\
$\Delta \mathrm{CO}_{2}(\mathrm{ppm})$ & $-\mathrm{a}$ & $8.5 \pm 2.5$ & $5.3 \pm 2.5$ & $10.2 \pm 2.5$ & $7.4 \pm 1.0$ & $3.1 \pm 1.0$ \\
$\Delta \mathrm{CO}(\mathrm{ppb})$ & $362 \pm 10$ & $57 \pm 10$ & $39 \pm 10$ & $85 \pm 10$ & $333 \pm 10$ & $91 \pm 10$ \\
$\mathrm{ER}_{\mathrm{CO}}(\mathrm{mmol} / \mathrm{mol})$ & - & - & - & - & $70.7 \pm 11.7$ & $46.1 \pm 20.0$ \\
$\mathrm{O}_{3}(\mathrm{ppb})$ & 24.7 & 81.2 & 59.5 & 84.1 & 69.0 & 42.4 \\
$\mathrm{~N}_{3}-5 \mathrm{~nm}\left(\mathrm{~cm}^{-3}\right)$ & 90 & 398 & 118 & 596 & 385 & 528 \\
$\mathrm{~N}_{3-200 \mathrm{~nm}^{-3}\left(\mathrm{~cm}^{-3}\right)}$ & 270 & 760 & 819 & 1971 & 3796 & 2688 \\
$\mathrm{EBC}\left(\mu \mathrm{g} \mathrm{m}^{-3}\right)$ & $-\mathrm{b}$ & 0.02 & 0.17 & 0.30 & 1.37 & 0.62 \\
$\Delta \mathrm{EBC} / \Delta \mathrm{CO}$ & $-\mathrm{b}$ & 0.3 & 4.4 & 3.5 & 4.1 & 6.8 \\
$\left(\mathrm{ng} \mathrm{m}{ }^{-3} \mathrm{ppb}^{-1}\right)$ & & & & & & 1 \\
\hline Flexpart age & 13 & 10 & 5 & 2 & & 1 \\
$($ days $)$ & & & & & &
\end{tabular}

a No background was applicable to Plume 1.

b No data available.

$3 \mathrm{~km}$ altitude (Fig. 7). Plume 1 is associated to a well correlated $\left(R^{2}=0.78, p=0.007, n=10\right)$ negative $(\sim-20 \mathrm{ppb})$ $\mathrm{O}_{3}$ excursion, resulting in a low mixing ratio of $24.7 \mathrm{ppb}$. The $\mathrm{O}_{3} / \mathrm{CO}$ regression slope is $-0.04 \mathrm{ppb} \mathrm{O}_{3} / \mathrm{ppbCO}$. This might indicate that $\mathrm{O}_{3}$ loss processes dominated over photochemical production (Val Martin et al., 2006; Real et al., 2007), or that mixing with air having low $\mathrm{O}_{3}$ mixing ratio occurred in the boundary layer. $\mathrm{O}_{3}$ losses could occur through reaction with organic compounds on biomass burning aerosols and concurrently with night-time oxidation of volatile organic compounds but the combination of mechanisms is not fully explained yet (Val Martin et al., 2006). No enhancement of particle concentration was observed, probably due to wet scavenging from the plume. $\mathrm{CO}_{2}$ enhancement in this plume appears to be very weak relative to surrounding air, but is difficult to quantify due to the absence of a well defined background. No EBC observations were available for this plume.

Plume 1 is predicted to have a very low $\mathrm{CO}$ excess $(\triangle \mathrm{CO}=8 \mathrm{ppb})$ by the FLEXPART backward simulations and its age is 13 days. The observed low number concentration of fine aerosol is consistent with an aged plume. As discussed above, these measurements were likely made at the edge of a major plume predicted in the FLEXPART forward run just to the north of the flight track, over the East Siberian Sea (Fig. 5). The model suggests no BC in this plume but a significant $\mathrm{CO}$ enhancement (30-40 ppb, $1 \mathrm{~km}$ thick) near the flight track (much higher mixing ratios further north), consistent with the measurements (fine particle number concentrations near background levels; EBC data missing). The vertical curtain plots in Fig. 5 suggest that plumes 1 and 2 are simulated at altitudes matching well the observations, albeit plume 1 is slightly too high by $\sim 1.5 \mathrm{~km}$.
Plume 2 corresponds to an upper-tropospheric $\mathrm{CO}$ enhancement of $57 \mathrm{ppb}$ (Table 1), encountered at $6 \mathrm{~km}$ altitude (Fig. 7). It is capped by a layer with a stratospheric signature, identified by increasing $\mathrm{O}_{3}$ mixing ratios (up to $220 \mathrm{ppb}$ ) and decreasing relative humidity, at flight ceiling. This stratospheric signature is further confirmed by the FLEXPART backward simulation, with more than $60 \%$ of particles originating from the stratosphere one day or less before measurement. In addition to elevated $\mathrm{CO}$ the fire plume has a weak BC enhancement of $0.02 \mu \mathrm{g} \mathrm{m}^{-3}$. The FLEXPART simulation indicates that the BB-related $\mathrm{CO}$ enhancement in this airmass occurred 10 days prior to encounter (Table 1). $\mathrm{O}_{3}$ average mixing ratio in this plume is $81.2 \mathrm{ppb}$. CO is negatively correlated both with $\mathrm{CO}_{2}\left(R^{2}=0.84 ; p=<0.001\right.$; $n=32$, slope $=-27.9 \pm 2.1)$ and $\mathrm{O}_{3}\left(R^{2}=0.24 ; p=0.004\right.$; slope: $-0.79 \pm 0.13)$. An explanation for these anticorrelations is partial mixing of the plume with air of recent stratospheric origin immediately above.

Plume 3 shows no correlation between $\mathrm{CO}$ and $\mathrm{O}_{3} \cdot \mathrm{CO}_{2}$ data are scarce for this plume because of a concurrent inflight calibration. This plume was encountered on a flight plateau at $3.5 \mathrm{~km}$ altitude and was not found above this altitude on descent to/ascent from this plateau. A slight BC increase was observed for this plume $\left(0.17 \mu \mathrm{g} \mathrm{m}^{-3}\right)$. FLEXPART overestimated the BB CO enhancement in this plume ( $\sim 100 \mathrm{ppb})$ compared to the measurements ( $39 \mathrm{ppb})$.

Plume 4 differs significantly from plumes 2 and 3 since $\mathrm{CO}$ is positively correlated to $\mathrm{CO}_{2}\left(R^{2}=0.84 ; p=<0.001\right.$; $n=13$; slope: $57.8 \pm 8.1)$ and to $\mathrm{O}_{3}\left(R^{2}=0.40 ; p=0.02 ; n=13\right.$; slope: $7.2 \pm 2.0$ ). It has a strong excess of ultrafine particles, with particles in the range $20-200 \mathrm{~nm}$ totalling $2000 \mathrm{~cm}^{-3}$. EBC excess is also significant with $0.3 \mu \mathrm{g} \mathrm{m}^{-3}$. It constitutes a thin layer of $400 \mathrm{~m}$ thickness at $6 \mathrm{~km}$ altitude. 


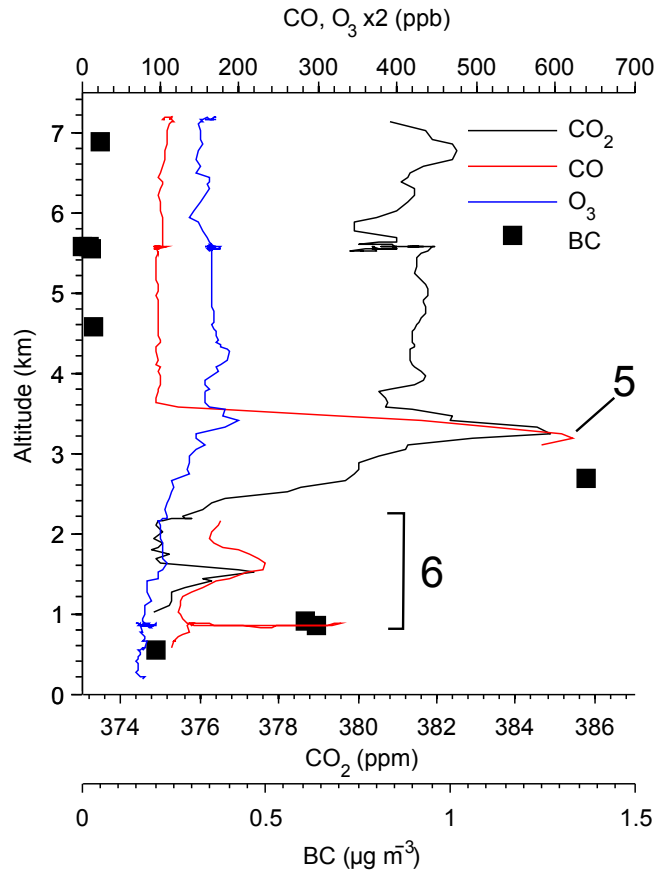

Fig. 8. Vertical profiles of $\mathrm{CO}$ (red line), $\mathrm{CO}_{2}$ (black line), $\mathrm{O}_{3}$ (blue line) and EBC (black squares) shortly before landing in Yakutsk. Position of plumes 5 and 6 is indicated.

As the aircraft was descending toward Yakutsk, close to the fire source area (Fig. 1), high $\mathrm{CO}$ mixing ratios were observed below $3 \mathrm{~km}$ (Fig. 8, plumes 5 and 6). Plume 5 exhibits a $\mathrm{CO}$ mixing ratio up to $600 \mathrm{ppb}$ and caps a couple of other high-CO plumes (varying between 150 and $300 \mathrm{ppb}$ ) down to the surface (labelled " 6 " in Fig. 4a). The layering of plumes 5 and 6 is explained by the presence of two temperature inversion layers at corresponding heights (not shown). FLEXPART estimates the age of these plumes at less than 1 day. High tracer mixing ratios, strong correlation of $\mathrm{CO}$ with particles concentrations, $\mathrm{EBC}$ and $\mathrm{CO}_{2}$ observed in plumes 5 and 6 , combined with the $<1$ day of travel time from the fire suggest that these observations can be used to determine the emission ratios of the species observed.

\subsection{Emission ratio, emission factor and combustion efficiency}

Combustion efficiency (CE) is defined as the ratio between the carbon emitted as $\mathrm{CO}_{2}$ to the total amount of carbon emitted to the atmosphere (Ward et al., 1991).

$\mathrm{CE}=\frac{\mathrm{C}_{\left[\mathrm{CO}_{2}\right]}}{\mathrm{C}_{\left[\mathrm{CO}_{2}\right]}+\mathrm{C}_{[\mathrm{CO}]}+\mathrm{C}_{\left[\mathrm{CH}_{4}\right]}+\mathrm{C}_{[\mathrm{NMHC}]}+\mathrm{C}_{[\mathrm{PC}]}}$

A CE higher than $90 \%$ is an indicator of a flaming fire, whereas a CE lower than $90 \%$ indicates a smoldering fire. This ratio is sensitive essentially to $\mathrm{CO}$ and $\mathrm{CO}_{2}$ as these two species represent $95 \%$ of C emissions (Ward et al., 1991). In the case where not all species are measured, a modified combustion efficiency can be used where the carbon emitted as $\mathrm{CO}$ and $\mathrm{CO}_{2}$ approximates the total amount of carbon emitted. Based on the measurements in plumes 5 and 6 we estimate a CE of $90 \pm 3 \%$, which does not discriminate between flaming and smoldering phases of the fire.

Emission factors were calculated using the carbon mass balance method (Ward et al., 1991). This method is based on the partial oxidation of combustion fuel into $\mathrm{CO}_{2}$ and other incomplete combustion products, including $\mathrm{CO}$, hydrocarbons and particulate matter. The emission factor (EF) of a species $\mathrm{X}$ corresponds to the mass of $\mathrm{C}$ emitted per mass of dry matter burned according to Eq. (3).

$\mathrm{EF}_{\mathrm{X}}=\frac{[\mathrm{X}]}{\mathrm{C}_{\left[\mathrm{CO}_{2}\right]}+\mathrm{C}_{[\mathrm{CO}]}+\mathrm{C}_{\left[\mathrm{CH}_{4}\right]}+\mathrm{C}_{[\mathrm{NMHC}]}+\mathrm{C}_{[\mathrm{PC}]}}$

where $\mathrm{C}_{[\mathrm{X}]}$ refers to the amount of $\mathrm{C}$ released as species $\mathrm{X}$. The emission ratios for $\mathrm{CO}$ and particles relative to $\mathrm{CO}_{2}$ are given according to Eq. (4), in terms of concentration and mixing ratio:

$\mathrm{ER}_{\mathrm{X}}=\frac{[\mathrm{X}]}{\mathrm{C}_{\left[\mathrm{CO}_{2}\right]}}=\frac{\Delta[\mathrm{X}] / \mathrm{M}_{\mathrm{X}}}{\Delta\left[\mathrm{CO}_{2}\right] / \mathrm{M}_{\mathrm{CO}_{2}}}$

where $\mathrm{M}_{\mathrm{X}}$ is the molecular mass of compound $\mathrm{X}$. Estimates for the terms of Eqs. (3) and (4) are provided by the measurement of the excess concentrations of these compounds in very recent smoke close to the source. Excess concentrations are considered relative to a surrounding clean air background. ER can be also taken as the regression slope between high-frequency measurements of the two species throughout the plume. In the following, $\mathrm{ER}_{\mathrm{CO}}$ is based on linear regression, while $\mathrm{ER}_{\mathrm{BC}}$ is based on maximum enhancement ratio with measurement technique having a lower frequency of acquisition. However in the case of $\mathrm{CO}$ the two methods were tried and give results within $10 \%$ of each other.

The CO emission per kg dry biomass burned (EF) can alternatively be derived from the ER. Here we use the following equation:

$\mathrm{EF}_{\mathrm{CO}}=\mathrm{M}_{\mathrm{CO}} \times \frac{\mathrm{EF}_{\mathrm{CO}_{2}}}{\mathrm{M}_{\mathrm{CO}_{2}}} \times \mathrm{ER}_{\mathrm{CO}}$

Because we do not observe directly $\mathrm{EF}_{\mathrm{CO}_{2}}$, we hypothesize that values from the literature for Siberia can be applied. From prescribed forest fire experiments in Siberia, Cofer et al. (1996) suggest a value of $1475 \pm 40 \mathrm{~g} \mathrm{CO}_{2} \mathrm{~kg}^{-1}$, lower than in a more recent experiment with $\mathrm{EF}_{\mathrm{CO}_{2}} \sim 1650 \mathrm{~g} \mathrm{~kg}^{-1}$ (McRae et al., 2006). The latter further identified a large range of $\mathrm{EF}_{\mathrm{CO}_{2}}$ depending on the fuel type, ranging from $1060 \mathrm{~g} \mathrm{~kg}^{-1}$ for moss and lichen to $1717 \mathrm{~g} \mathrm{~kg}^{-1}$ for rotten wood. Separating crown and smoldering fires, Cofer et al. (1998) report $1500 \pm 50$ for crown fire and $1100 \pm 50$ for smoldering emissions. Here we consider a range of $\mathrm{EF}_{\mathrm{CO}_{2}}$ values between 1475 and $1650 \mathrm{~g} \mathrm{~kg}^{-1}$, from the two prescribed burning in Siberian forest available in the literature (FIRESCAN Science Team, 1996; McRae et al., 2006). 
Accounting for observational and methodological errors, we obtain an $\mathrm{ER}_{\mathrm{CO}}$ of $66.5 \pm 3.9 \mathrm{mmol} \mathrm{mol}^{-1}$ and an $\mathrm{EF}_{\mathrm{CO}}$ of $65.5 \pm 10.8 \mathrm{~g} \mathrm{CO} \mathrm{kg}^{-1}$ from a linear regression of $\mathrm{CO}$ vs. $\mathrm{CO}_{2}$ in the plumes 5 and 6 . The uncertainty reported here should be considered with caution since we did not measure $\mathrm{EF}_{\mathrm{CO}_{2}}$ directly. Our $\mathrm{CO}$ emission factor is at the lower end of values reported in the literature for boreal forest fires. Observed $\mathrm{EF}_{\mathrm{CO}}$ values range from $68.8 \mathrm{~g} \mathrm{~kg}^{-1}$ (Cofer et al., 1989) up to $350 \pm 45 \mathrm{~g} \mathrm{~kg}^{-1}$ (Cofer et al., 1998) for Siberian smoldering taiga fires. However, the vast majority of data on boreal emission factors used as reference were obtained from North American boreal forest fires (Andreae and Merlet, 2001). Andreae and Merlet (2001) reported an average of $107 \pm 37 \mathrm{~g} \mathrm{~kg}^{-1}$ for extratropical forest fires (this value being the one used for the emissions in FLEXPART; see Stohl et al., 2007). In their prescribed burning experiments, McRae et al. (2006) found a range of $\mathrm{EF}_{\mathrm{CO}}$ between 98 and $135 \mathrm{~g} \mathrm{~kg}^{-1}$. Kajii et al. (2002) report their lower estimate of $\mathrm{EF}_{\mathrm{CO}}$ of $81 \mathrm{~g} \mathrm{CO} \mathrm{kg}^{-1}$ for crown and light surface fires.

During Siberian boreal forest fires, the total fuel consumption (below and above ground) likely ranges between $2.5 \mathrm{~kg} \mathrm{~m}^{-2}$ dry matter (Cahoon et al., 1994) and $3.7 \mathrm{~kg} \mathrm{~m}^{-2}$ (FIRESCAN Science Team, 1996). An average of 45\% of $\mathrm{C}$ in dry fuel (Cahoon et al., 1994) suggests that 1.1$1.7 \mathrm{~kg} \mathrm{C} \mathrm{m}^{-2}$ are available to combustion. As a result, a total of between 1.25 and $3.10 \mathrm{tCO}$ (ha burned) ${ }^{-1}$ may have been emitted by the forest fires during this period. This compares with the estimate of Kajii et al. (2002) of 2.5-4.5 t CO ha ${ }^{-1}$ for the intense fire years of 1987 and 1998. Our values can also be expressed as a northern hemispheric 3.0-7.2 ppb CO increase per million hectare burned, a range higher than found in a regression analysis by Wotawa et al. (2001) for Russian fires ( $3 \mathrm{ppbCO} \mathrm{Mha}^{-1}$ ). This can be put further in perspective when considering that 5-10 Mha are burnt each year (with large inter-annual variability) in Siberia (Conard et al., 2002).

Siberian forest fires are comparatively less intense than North American boreal fires, with more surface-type fires in Siberia (Wooster and Zhang, 2004). As a result, their combustion should be comparatively less efficient. However here the combustion efficiency is not clearly indicative of a smoldering surface fire and the $\mathrm{EF}_{\mathrm{CO}}$ is at the lower end of the range of values reported in the literature, suggesting that we sample emissions from the flaming phase of the forest fire.

The EBC emission ratio is estimated to $0.52 \pm 0.07 \mathrm{~g} \mathrm{BC} \mathrm{kg}^{-1}$. Calculation of this emission ratio is based on maximum enhancements ratio in the plume. This is in line with the results of Andreae and Merlet (2001) who obtained the value $0.56 \pm 0.19 \mathrm{~g} \mathrm{BC} \mathrm{kg}^{-1}$. In constructing their inventory, Lavoué et al. (2000) used the value $0.75 \mathrm{~g} \mathrm{BC} \mathrm{kg}^{-1}$ for boreal forests, slightly higher than the values reported here. Our data suggests a total of 0.05-0.09 t BC (ha burned) ${ }^{-1}$ may have been emitted during the period.
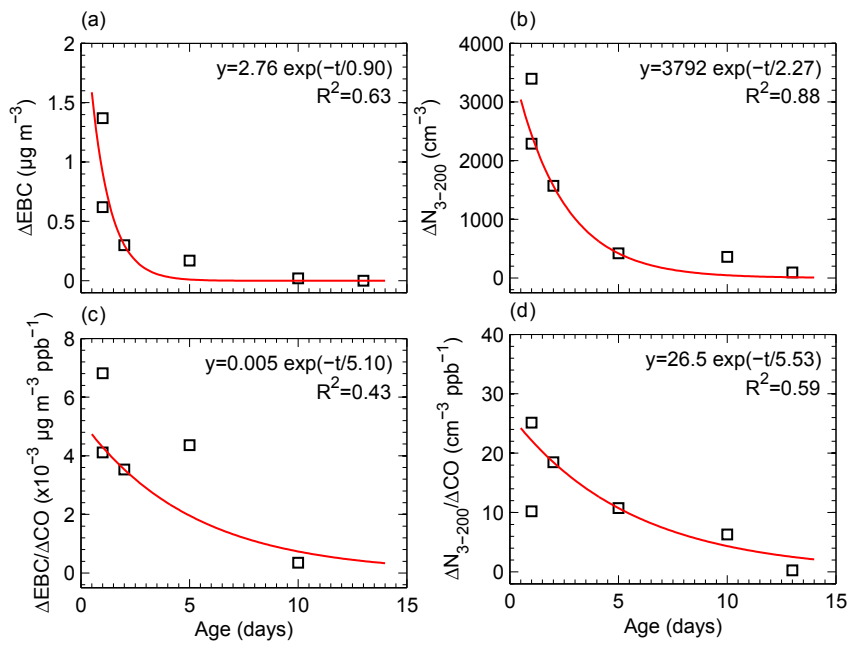

Fig. 9. Aerosol concentration enhancements observed during flight 17 as a function of FLEXPART transport time for (a) $\triangle \mathrm{EBC}$, (b) $\Delta \mathrm{N}_{3-200}$ (ultrafine and accumulation mode particles), and enhancement ratios for (c) $\Delta \mathrm{EBC} / \Delta \mathrm{CO}$, (d) $\Delta \mathrm{N}_{3-200} / \Delta \mathrm{CO}$ as a function of transport time. An exponential function is fitted to the data (red line).

\subsection{Aerosol removal time scales}

As we have shown in Fig. 4, the aircraft sampled several smoke plumes that were emitted in the same fire region, between Lake Baikal and Yakutsk. However, these plumes have different ages ranging between 1 and 13 days, and a decrease in EBC mass concentration and particle number concentration is expected due to removal and mixing processes. Figure 9 shows aerosol number concentration enhancement $\Delta \mathrm{N}$, black carbon concentration enhancement $\triangle \mathrm{EBC}$ as well as the enhancement ratios $\Delta \mathrm{N} / \Delta \mathrm{CO}$ and $\Delta \mathrm{EBC} / \Delta \mathrm{CO}$ as a function of plume age (Table 1). EBC concentrations decrease exponentially with time. The exponential fit model explains $R^{2}=63 \%$ of the variance of the signal for $\triangle \mathrm{EBC}$ (Fig. 9a text inset). Over 10 days, $\triangle \mathrm{EBC}$ decreases by slightly less than two orders of magnitude and $\triangle \mathrm{EBC} / \triangle \mathrm{CO}$ enhancement ratio by roughly one order of magnitude. The e-folding lifetime of EBC against removal processes is estimated at 5.1 days (see text inset in Fig. 9c) using the exponential fit of $\triangle \mathrm{EBC} / \triangle \mathrm{CO}\left(R^{2}=0.43\right)$. The stronger reduction of $\mathrm{EBC}$ concentrations relative to enhancement ratios is due to plume dilution by mixing with background air, which affects both EBC and CO.

The decrease of biomass burning EBC with transport time is attributed to mixing and removal processes enhanced by coating of particles by hydrophilic organics. Jacobson (2001) found in a modelling study (including internal mixing and removal processes such as coagulation, condensation, deposition, equilibrium water uptake and rainout) that only $20 \%$ by mass of the primary submicron $\mathrm{BC}$ remain after 5 days. This suggests that our estimated $\mathrm{BC}$ lifetime against removal is 
valid for $\mathrm{BC}$ particles in the submicron range. Our estimated EBC lifetime of 5.1 days supports assumed BC lifetime in other studies. Stohl (2006) reviewed lifetimes used in three modelling studies ranging between 3 and 7 days (respectively $6 \pm 2$ days (Park et al., 2005), 3-4 days (Liu et al., 2005), and 7.3 days (Koch and Hansen, 2005)).

Ultrafine particle number concentrations are also decreasing with plume age (Fig. 9b and d), with an exponential fit that explains $R^{2}=0.59$ of the variance between age and the $\Delta \mathrm{N} / \Delta \mathrm{CO}$ ratio. The lifetime implied by the exponential fit is 5.5 days (Fig. 9d). Possible sinks for particles in this size range are coagulation onto pre-existing larger particles or removal processes. The slightly faster decrease of EBC concentration (5.1 days) relative to the decrease in total aerosol number concentration is due to the difference between sizelimited sensitivities of the two measurement techniques. The intercept indicates that the ultra fine particle emission ratio was $\sim 26 \mathrm{~cm}^{-3} \mathrm{ppb}^{-1}$. The values found for $\Delta \mathrm{N} / \Delta \mathrm{CO}$ are consistent with other estimates at various plume ages, obtained essentially in the tropics (Andreae et al., 1994, 2001). For example Andreae et al. (1994) found for plumes of age 2-6 days a $\Delta \mathrm{N} / \Delta \mathrm{CO}=2-8$ for sizes above $0.1 \mu \mathrm{m}$ and $8-18$ for Aitken nuclei (more comparable to our case). In our estimates of lifetimes, the error in the regression of the concentration ratios is linked to the imprecision of airmass age determination (error estimated to \pm 1 day) and to the value chosen as a background for particles concentrations (within $\pm 50 \mathrm{~cm}^{-3}$ ).

\section{Conclusions}

In the framework of the YAK-AEROSIB/POLARCAT experiments we carried out intensive airborne campaigns to measure the tropospheric distribution of trace gases and aerosols including equivalent black carbon (EBC). The background mixing ratios of trace gases were generally similar to previous YAK-AEROSIB summer campaigns. However, several layers with high $\mathrm{CO}$, aerosol and $\mathrm{BC}$ concentrations were observed on three flights, which were caused by forest fires in Eastern Siberia near Yakutsk. During one flight, on 11 July 2008, several plumes were observed that all originated from the same fires but took different atmospheric transport routes.

Based on the data acquired during a vertical profile close to the fires, we derived an average $\mathrm{CO}$ emission factors of $65.5 \pm 10.8 \mathrm{~g} \mathrm{CO}$ per kilogram of dry matter burned. This $\mathrm{CO}$ emission factor, although rather low compared to values in the literature, suggests that fires in Siberia could cause an increase in northern hemispheric $\mathrm{CO}$ mixing ratios of 3.0-7.2 ppb per million hectares (Mha) burned, with up to $\sim 10$ Mha burning annually in Siberia. For EBC we obtained an emission factor of $0.52 \pm 0.07 \mathrm{~g} \mathrm{BC} \mathrm{kg}^{-1}$. The emission ratio of ultra-fine particles $(3.5-200 \mathrm{~nm})$ was $26 \mathrm{~cm}^{-3}$ $(\mathrm{ppbCO})^{-1}$, consistent with other airborne studies.
A variety of plumes were encountered during the 11 July flight. Their ages ranged from less than 1 day to 13 days, as determined from backward simulations with the Lagrangian particle dispersion model FLEXPART. The most aged plumes were found in the free troposphere near the Siberian Arctic coast at approximately $70^{\circ} \mathrm{N}$, while the freshest plumes were found near Yakutsk, not far from the fires. Smoke plumes were lifted by several frontal systems passing through the study area.

High EBC concentrations were observed near the fire (up to $1.5 \mu \mathrm{g} \mathrm{m}^{-3}$ ), whereas aged plumes had near-background EBC concentrations $\left(0.02 \mu \mathrm{g} \mathrm{m}^{-3}\right)$. Using an exponential fit to the observed time dependence of EBC and ultrafine particle enhancement ratios with $\mathrm{CO}$, our observations suggest lifetimes in the Siberian troposphere of 5.1 days for EBC and 5.5 days for ultrafine particles. The most aged plume (13 days) had a strong negative correlation between $\mathrm{CO}$ and $\mathrm{O}_{3}\left(R^{2}=0.78\right)$ with a $\mathrm{O}_{3} / \mathrm{CO}$ regression slope of $-0.04 \mathrm{ppb} \mathrm{O}_{3} / \mathrm{ppb} \mathrm{CO}$, indicating that $\mathrm{O}_{3}$ destruction dominated over photochemical production in this aged plume.

Acknowledgements. We thank the scientific and flight crews for carrying out successfully the campaigns. Burnt area product was provided by A. I. Sukhinin. Thanks to D. McRae and B. J. Stocks for useful discussions and support. M. Ramonet, J.-L. Teffo, I. G. Granberg and G. S. Golitsyn are acknowledged for their contribution to the YAK-AEROSIB project. This study was funded by ANR as a part of POLARCAT France (grant BLAN06-1_137670), by the Norwegian Research Council as part of POLARCAT-Norway, and by CEA, CNRS, French Ministry of Foreign Affairs, the Russian Foundation for Basic Research (grants 07-05-00645, 08-05-10033 and 08-05-92499), and the Russian Academy of Science.

Edited by: J. W. Bottenheim

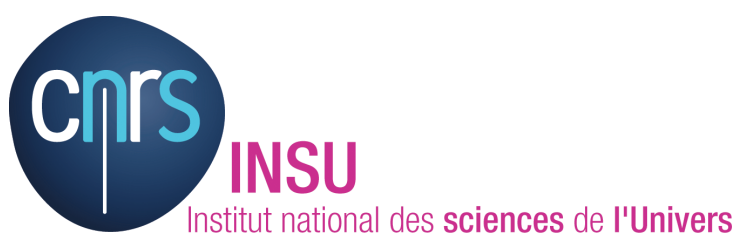

The publication of this article is financed by CNRS-INSU.

\section{References}

Andreae, M. O., Anderson, B. E., Blake, D. R., Bradshaw, J. D., Collins, J. E., Gregory, G. L., Sachse, G. W., and Shipham, M. C.: Influence of plumes from biomass burning on atmospheric chemistry over the equatorial and tropical South Atlantic during CITE 3, J. Geophys. Res.-Atmos., 99(D6), 12793-12808, 1994.

Andreae, M. O. and Merlet, P.: Emission of trace gases and aerosols from biomass burning, Global Biogeochem. Cy., 15(4), 955-966, 2001.

Andreae, M. O., Artaxo, P., Fischer, H., Freitas, S. R., Gregoire, J. M., Hansel, A., Hoor, P., Kormann, R., Krejci, R., Lange, L., 
Lelieveld, J., Lindinger, W., Longo, K., Peters, W., de Reus, M., Scheeren, B., Dias, M. A. F. S., Strom, J., van Velthoven, P. F. J., and Williams, J.: Transport of biomass burning smoke to the upper troposphere by deep convection in the equatorial region, Geophys. Res. Lett., 28(6), 951-954, 2001.

Arshinov M., Belan, B. D., Nedelec, P., Paris, J.-D., and Machida, T.: Spatial distribution of nanoparticles in the free troposphere over Siberia, in: Nucleation and Atmospheric Physics, 17th International Conference on Nucleation and Atmospheric Aerosols, edited by: O’Dowd, C. D. and Wagner, P. E., Springer, 819-823, 2007.

Cahoon Jr., D. R., Stocks, B. J., Levine, J. S., Cofer III, W. R., and Pierson, J. M.: Satellite analysis of the severe 1987 forest fires in northern China and southeastern Siberia, J. Geophys. Res.Atmos., 99, 18627-18638, 1994.

Cofer III, W. R., Levine J. S., Sebacher, D. I., Winstead, E. L., Riggan, P. J., Stocks, B. J., Brass, J. A., Ambrosia, V. G., and Boston, P. J.: Trace gas emissions from chaparral and boreal forest fires, J. Geophys. Res.-Atmos., 94, 2255-2259, 1989.

Cofer III, W. R., Winstead, E. L., Stocks B. J., Overbay, L. W., Goldammer, J. G., Cahoon, D. R., and Levine, J. S.: Emissions from boreal forest fires: are the atmospheric impacts underestimated?, in: Global Biomass Burning and Global Change, edited by: Levine, J. S., MIT Press, Cambridge, Mass., 834-839, 1996.

Cofer III, W. R., Winstead, E. L. Stocks, B. J., Goldammer, J. G., and Cahoon, D. R.: Crown fire emissions of $\mathrm{CO}_{2}, \mathrm{CO}, \mathrm{H}_{2}, \mathrm{CH}_{4}$, and TNMHC from a dense jack pine boreal forest fire, Geophys. Res. Lett., 25, 3919-3922, 1998.

Conard, S. G., Sukhinin, A. I., Stocks, B. J., Cahoon, D. R., Davidenko, E. P., and Ivanova, G. A.: Determining effects of area burned and fire severity on carbon cycling and emissions in Siberia, Clim. Change, 55, 197-211, 2002.

FIRESCAN Science Team: Fire in Ecosystems of Boreal Eurasia: The Bor Forest Island Fire Experiment, Fire Research Campaign Asia-North (FIRESCAN), in: Biomass Burning and Global Change, edited by: Levine, J. S., MIT Press, Cambridge, Mass., 848-873, 1996.

Flanner, M. G., Zender, C. S., Randerson, J. T., and Rasch, P. J.: Present day climate forcing and response from black carbon in snow, J. Geophys. Res.-Atmos., 112, D11202, doi:10.1029/2006JD008003, 2007.

Generoso, S., Bey, I., Attié, J.-L., and Bréon, F.-M.: A satelliteand model-based assessment of the 2003 Russian fires: Impact on the Arctic region, J. Geophys. Res.-Atmos., 112, D15302, doi:10.1029/2006JD008344, 2007.

Giglio, L., Descloitres, J., Justice, C. O., and Kaufman, Y.: An enhanced contextual fire detection algorithm for MODIS, Remote Sens. Environ., 87, 273-282, 2003.

Jacobson, M. Z.: Strong radiative heating due to the mixing state of black carbon in atmospheric aerosols, Nature, 409, 695-697, 2001.

Jain, A. K., Tao, Z., Yang, X., and Gillespie, C.: Estimates of global biomass burning emissions for reactive greenhouse gases $(\mathrm{CO}$, NMHCs, and NOx) and CO2, J. Geophys. Res.-Atmos., 111, D06304, doi:10.1029/2005JD006237, 2006.

Kajii, Y., Kato, S., Streets, D. G. Tsai, N. Y., Shvidenko, A., Nilsson, S., McCallum, I., Minko, N. P., Abushenko, N., Altyntsev, D., and Khodzer, T. V.: Boreal forest fires in Siberia in 1998: Estimation of area burned and emissions of pollutants by advanced very high resolution radiometer satellite data, J. Geophys. Res.Atmos., 107(D24), 4745, doi:10.1029/2001JD001078, 2002.

Kasischke, E. S., Hyer, E. J., Novelli, P. C., Bruhwiler, L. P., French, N. H. F., Suckhinin, A. I., Hewson, J. H., and Stocks, B. J.: Influences of boreal fire emissions on Northern Hemisphere atmospheric carbon and carbon monoxide, Global Biogeochem. Cy., 19, GB1012, doi:10.1029/2004GB002300, 2005.

Koch, D. and Hansen, J.: Distant origins of Arctic Black Carbon: A GISS ModelE experiment, J. Geophys. Res.-Atmos., 110, D04204, doi:10.1029/2004JD005296, 2005.

Lavoué, D. C., Liousse, C., Cachier, H., Stocks, B. J., and Goldammer, J. G.: Modelling of carbonaceous particles emitted by boreal and temperate wildfires at northern latitudes, J. Geophys. Res.-Atmos., 105, 26871-26890, 2000.

Lehsten, V., Tansey, K., Balzter, H., Thonicke, K., Spessa, A., Weber, U., Smith, B., and Arneth, A.: Estimating carbon emissions from African wildfires, Biogeosciences, 6, 349-360, 2009, http://www.biogeosciences.net/6/349/2009/.

Liu, X. H., Penner, J. E., and Herzog, M.: Global modeling of aerosol dynamics: Model description, evaluation, and interactions between sulfate and nonsulfate aerosols, J. Geophys. Res.Atmos., 110(D18), D18206, doi:10.1029/2004JD005674, 2005.

McRae, D. J., Conard, S. G., Ivanova, G. A., Sukhinin, A. I., Baker, S. P., Samsonov, Y. N., Blake, T. W., Ivanov, V. A., Ivanov, A. V., Churkina, T. V., Hao, W. M., Koutzenogij, K. P., and Kovaleva, N.: Variability of fire behavior, fire effects, and emissions in scotch pine forests of Central Siberia, Mitigation and Adaptation Strategies for Global Change, 11(1), 45-74, doi:10.1007/s11027-006-1008-4, 2006.

Nakazawa, T., Sugawara, S., Inoue, G., Machida, T., Makshyutov, S., and Mukai, H.: Aircraft measurements of the concentrations of $\mathrm{CO}_{2}, \mathrm{CH}_{4}, \mathrm{~N}_{2} \mathrm{O}$, and $\mathrm{CO}$ and the carbon and oxygen isotopic ratios of $\mathrm{CO}_{2}$ in the troposphere over Russia, J. Geophys. Res.Atmos., 102(D3), 3843-3859, 1997.

Nédélec, P., Cammas, J.-P., Thouret, V., Athier, G., Cousin, J.-M., Legrand, C., Abonnel, C., Lecoeur, F., Cayez, G., and Marizy, C.: An improved infrared carbon monoxide analyser for routine measurements aboard commercial Airbus aircraft: technical validation and first scientific results of the MOZAIC III programme, Atmos. Chem. Phys., 3, 1551-1564, 2003, http://www.atmos-chem-phys.net/3/1551/2003/.

Nédélec, P., Thouret, V., Brioude, J., Sauvage, B., Cammas, J. P., and Stohl, A.: Extreme CO concentrations in the upper troposphere over northeast Asia in June 2003 from the in situ MOZAIC aircraft data, Geophys. Res. Lett., 32(14), L14807, doi:10.1029/2005GL023141, 2005.

Olivier, J. G. J. and Berdowski, J. J. M.: Global emissions sources and sinks, in: The Climate System, edited by: Berdowski, J., Guicherit, R., and Heij, B. J., A. A. Balkema Publishers/Swets \& Zeitlinger Publishers, Lisse, The Netherlands, ISBN $905809255-$ 0, 33-78, 2001.

Panchenko, M. V., Kozlov, V. S., Terpugova, S. A., Shmargunov, V. P., and Burkov, V. V.: Simultaneous measurements of submicron aerosol and absorbing substance in the height range up to $7 \mathrm{~km}$, in: Tenth ARM Science Team Meeting Proceeding, San Antonio, Texas, 13-17 March, www.arm.gov/publications/ proceedings/conf10/extended_abs/panchenko_mv.pdf, 2000.

Paris, J.-D., Arshinov, M., Ciais, P., Belan, B., and Nedelec, P.: Large-scale aircraft observations of ultra-fine and fine par- 
ticle concentrations in the remote Siberian troposphere: New particle formation studies, Atmos. Environ., 43(6), 1302-1309, doi:10.1016/j.atmosenv.2008.11.032, 2009a.

Paris, J.-D., Stohl, A., Ciais, P., Nédélec, P., Belan, B. D., Arshinov, M. Y., and Ramonet, M.: Source-receptor relationships for airborne measurements of $\mathrm{CO}_{2}, \mathrm{CO}$ and $\mathrm{O}_{3}$ above Siberia: a cluster-based approach, Atmos. Chem. Phys. Discuss., 9, 6207$6245,2009 b$,

http://www.atmos-chem-phys-discuss.net/9/6207/2009/.

Paris, J.-D., P. Ciais, P. Nédélec, M. Ramonet, B. D. Belan, M. Yu. Arshinov, G. S. Golitsyn, I. Granberg, A. Stohl, G. Cayez, G. Athier, F. Boumard, and J.-M. Cousin: The YAK-AEROSIB transcontinental aircraft campaigns: new insights on the transport of $\mathrm{CO}_{2}, \mathrm{CO}$ and $\mathrm{O}_{3}$ across Siberia, Tellus B, 60(4), 551568, doi:10.1111/j.1600-0889.2008.00369.x, 2008.

Park, R. J., Jacob, D. J., Palmer, P. I., Clarke, A. D., Weber, R. J., Zondlo, M. A., Eisele, F. L., Bandy, A. R., Thornton, D. C., Sachse, G. W., and Bond, T. C.: Export efficiency of black carbon aerosol in continental outflow: global implications, J. Geophys. Res.-Atmos., 110, D11205, doi:10.1029/2004JD005432, 2005.

Pommier, M., Turquety, S., Clerbaux, C., et al.: Pollution plume transport to the Arctic as seen by IASI during summer 2008, Atmos. Chem. Phys. Discuss., in preparation, 2009.

Quinn, P. K., Bates, T. S., Baum, E., Doubleday, N., Fiore, A. M., Flanner, M., Fridlind, A., Garrett, T. J., Koch, D., Menon, S., Shindell, D., Stohl, A., and Warren, S. G.: Short-lived pollutants in the Arctic: their climate impact and possible mitigation strategies, Atmos. Chem. Phys., 8, 1723-1735, 2008,

http://www.atmos-chem-phys.net/8/1723/2008/.

Real, E., Law, K. S., Weinzierl, B., Fiebig, M., Petzold, A., Wild, O., Methven, J., Arnold, S., Stohl, A., Huntrieser, H., Roiger, A., Schlager, H., Stewart, D., Avery, M., Sachse, G., Browell, E., Ferrare, R., and Blake D.: Processes in?uencing ozone levels in Alaskan forest fire plumes during long-range transport over the North Atlantic, J. Geophys. Res.-Atmos., 112, D10S41, doi:10.1029/2006JD007576, 2007.

Reid, J. S., Koppmann, R., Eck, T. F., and Eleuterio, D. P.: A review of biomass burning emissions part II: intensive physical properties of biomass burning particles, Atmos. Chem. Phys., 5, 799825,2005 ,

http://www.atmos-chem-phys.net/5/799/2005/.

Seibert, P. and Frank, A.: Source-receptor matrix calculation with a Lagrangian particle dispersion model in backward mode, Atmos. Chem. Phys., 4, 51-63, 2004,

http://www.atmos-chem-phys.net/4/51/2004/.

Stohl, A.: Characteristics of atmospheric transport into the Arctic troposphere, J. Geophys. Res.-Atmos. 111, D11306, doi:10.1029/2005JD006888, 2006.

Stohl, A., Forster, C., Frank, A., Seibert, P., and Wotawa, G.: Technical note: The Lagrangian particle dispersion model FLEXPART version 6.2, Atmos. Chem. Phys., 5, 2461-2474, 2005, http://www.atmos-chem-phys.net/5/2461/2005/.

Stohl, A., Berg, T., Burkhart, J. F., Fjae'raa, A. M., Forster, C., Herber, A., Hov, Ø., Lunder, C., McMillan, W. W., Oltmans, S., Shiobara, M., Simpson, D., Solberg, S., Stebel, K., Ström, J., Tørseth, K., Treffeisen, R., Virkkunen, K., and Yttri, K. E.: Arctic smoke - record high air pollution levels in the European Arctic due to agricultural fires in Eastern Europe in spring 2006, Atmos. Chem. Phys., 7, 511-534, 2007, http://www.atmos-chem-phys.net/7/511/2007/.

Stohl, A., Andrews, E., Burkhart, J. F., Forster, C., Herber, A., Hoch, S. W. , Kowal, D., Lunder, C., Mefford, T., Ogren, J. A., Sharma, S., Spichtinger, N., Stebel, K., Stone, R., Ström, J., Tørseth, K., Wehrli, C., and Yttri, K. E.: Pan-Arctic enhancements of light absorbing aerosol concentrations due to North American boreal forest fires during summer 2004, J. Geophys. Res.-Atmos., 111, D22214, doi:10.1029/2006JD007216, 2006.

Sukhinin, A. I., French, N. H. F., Kasischke, E. S., Hewson, J. H., Soja, A. J., Csiszar, I. A., Hyer, E. J., Loboda, T., Conrad, S. G., Romasko, V. I., Pavlichenko, E. A., Miskiv, S. I., and Slinkina, O. A.: AVHRR-based mapping of fires in Russia: New products for fire management and carbon cycle studies, Remote Sens. Environ., 93, 546-564, 2004.

Turquety, S., Logan, J. A., Jacob, D. J., Hudman, R. C., Leung, F. Y., Heald, C. L., Yantosca, R. M., Wu, S. L., Emmons, L. K., Edwards, D. P., and Sachse, G. W.: Inventory of boreal fire emissions for North America in 2004: Importance of peat burning and pyroconvective injection, J. Geophys. Res.-Atmos., 112, D1203, doi:10.1029/2006JD007281, 2007.

Val Martin, M., Honrath, R. E., Owen, R. C., Pfister, G., Fialho, P., and Barata, F.: Significant enhancements of nitrogen oxides, black carbon, and ozone in the North Atlantic lower free troposphere resulting from North American boreal wildfires, J. Geophys. Res.-Atmos., 111, D23S60, doi:10.1029/2006JD007530, 2006.

van der Werf, G. R., Randerson, J. T., Giglio, L., Collatz, G. J., Kasibhatla, P. S., and Arellano Jr., A. F.: Interannual variability in global biomass burning emissions from 1997 to 2004, Atmos. Chem. Phys., 6, 3423-3441, 2006,

http://www.atmos-chem-phys.net/6/3423/2006/.

Ward, D. E., Setzer, A., Kaufman, Y. J., and Rasmussen, R. A.: Characteristics of smoke emissions from biomass fires of the Amazon region-Base-A experiment, in: Global Biomass Burning, edited by: Levine, J. S., MIT Press, Cambridge MA, 394 402, 1991.

Warneke, C., Bahreini, R., Brioude, J., Brock, C. A., De Gouw, J., Fahey, D. W., Froyd, K. D., Holloway, J. S., Middlebrook, A., Miller, L., Montzka, S., Murphy, D. M., Peischl, J.,. Ryerson, T. B, Schwarz, J. P., Spackman, J. R., and Veres, P.: Biomass burning in Siberia and Kazakhstan as an important source for haze over the Alaskan Arctic in April 2008, Geophys. Res. Lett., 36, L02813, doi:10.1029/2008GL036194, 2009.

Wofsy, S. C., Fan, S.-M., Blake, D. R., Bradshaw, J. D., Sandholm, S. T., Singh, H. B., Sachse, G. W., and Harriss, R. C.: Factors influencing atmospheric composition over subarctic North America during summer, J. Geophys. Res.-Atmos., 99(D1), 18871897, 1994.

Wotawa, G., Novelli, P. C., Trainer, M., and Granier, C.: Interannual variability of summertime $\mathrm{CO}$ concentrations in the Northern Hemisphere explained by boreal forest fires in North America and Russia, Geophys. Res. Lett., 28, 4575-4578, 2001. 